\title{
Két év matrózélet
}

\author{
Richard Henry Dana: Két év matrózélet. (Fordítás) \\ Dana, Richard Henry: Two Years Before the Mast (Translation)
}

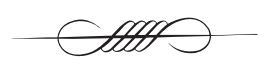

\section{A fordító megjegyzése}

$A$ Két év matrózélet fontosságát nem szükséges hangsúlyozni az amerikai közönség számára, azonban - ha eltekintünk az amerikanisztika tanszékek berkeitöl - jobbára ismeretlen a magyar olvasoközönség körében. Kalifornia ma az Egyesült Államoklegnépesebb állama, ahol a szerzö még akkor járt, amikor az gyéren lakott mexikói terület volt. A könyv nemcsak irodalmi értéke miatt tekinthetö értékes münek. Fontos forrása a korabeli hajóséletnek, a korabeli viszonyoknak. Bár Dana eredetileg humanitárius okokból - hogy a matrózok életkörülményeit javítsa - publikálta müvét, azt szép számmal forgatták a Kalifornia felé igyekvő amerikai telepesek is, mint a kevés könyv egyikét, ami úticéljukról egyáltalán elérhetö. A könyv ma amerikai klasszikusnak számit.

Időközben Kalifornia a világ egyik gazdasági és kulturális (többek között film-) centrumává nötte ki magát, aminek hatása világszerte, így nálunk is erösen érzékelhető. E távoli ország jelene ugyan betölti a képernyőket, és így sokszor a mindenapjainkat, de múltjára közel sincs ilyen rálátásunk. S ez nem feltétlenül van jól így. Ha az olvasnivaló szórakoztató minőségén túl valahol el akarom helyezni ennek a pár oldalnak az értékét, akkor azért tekinthetö elolvasásra érdemesnek, mert ezt az elmaradást, távolságot csökkentheti.

A most közreadott fordítás az első három fejezetre korlátozódik, és - különösen a szakszavak fordítása miatt - még nem tekinthetö véglegesnek. Észrevételeiket szívesen fogadom.

\section{Előszó}

Nem szívesen tárnám ezt a beszámolót a nagyközönség elé anélkül, hogy néhány szóban meg ne indokolnám, miért is adtam kiadására a fejem. Mr. Cooper müvei - „A révkalauz”és „A vörös kalóz”l - óta olyan sok történetet írtak már a tengerről, hogy nem szaporítanám ezek számát még eggyel, ha nem lenne rá nyomós okom.

Nathaniel Ames művét - az „Egy tengerész jegyzetei”2 címüt - leszámítva ugyanis, amely szórakoztató, ám elnagyolt és kapkodó stílusú, olyanok írtak csak a tengerről, akik élményeiket tengerésztisztként vagy utasként szerezték, s mint ilyenek, könyveik kevés kivételtől eltekintve nem a tényszerüség igényével íródtak.

Először is, a hadiflotta kötelékében az élet a tengeren - a katonás rend és fegyelem, a szokások, a napi rutin - eléggé elüt attól, mint amilyen az egy kereskedőhajón. Másodsorban, legyenek bár bármilyen szórakoztatóak és jól megírtak is könyveik, és íróik szemszögéből álljanak bármily közel is a valósághoz, mindenki számára egyértelmü, hogy a tengerésztiszt, aki úrként lép a hajóra - „kesztyűvel a kezén, ahogy a mondás tartja -, csak tiszttársaival elegyedik, és matrózhoz elvétve, legfeljebb csak a fedélzetmesteren keresztül szól, nyilván

1 James Fenimore Cooper: A révkalauz (1824, The Pilot); A vörös kalóz (1828, The Red Rover)

2 Eredeti címén: „Mariner's Sketches”; elfogadott magyar címről nincs tudomásom (a ford.) 
merőben más szemszögből látja a történéseket mint az egyszerü matróz.

A természetes érdeklődésen túl, amit mindenki mutat a számára ismeretlen és át nem élt dolgok irányába, az utóbbi években a köz különös figyelmet szentelt a matrózoknak és nagy rokonszenvet tanúsított irántuk. Mégis úgy gondolom, hogy az egyetlen kivétellel, amit már említettem, könyvírásra még senki sem vállalkozott azok közül, akik pedig igenis tudják, milyen a matrózélet. Az előfedélzet felől nem szólt még hang.

A következő oldalakon igyekszem pontos és autentikus képet adni arról a kicsit több mint két évről, amit matrózként szolgáltam le a vitorla alatt az amerikai kereskedőflottában. Mindehhez alapul naplómat vettem, amelyet ez idő alatt gondosan vezettem, s mindent úgy írtam le benne, ahogy az megesett. Mindeközben ügyeltem minden apró részletre, s hogy a jelenetek visszaadják a dolgok igazi ízét. Néhányat emiatt nehéz lehet jó érzettel végigolvasni, s közben időnként erős és durva szavak használatára kényszerültem. De igyekeztem ezeket minden alkalommal elhagyni, amikor a helyzet érzékeltetéséhez nem volt feltétlenül szükség rájuk. Szándékom, ami a könyv kiadására is késztetett, hogy az egyszerü matróz szemével mutassam be, milyen is az élet a tengeren - úgy a jó, mint egyben az árnyoldalt is.

A hajózásban nem jártas olvasó számára bizonyosan akadnak majd nem világos kifejezések, de a saját és társaim meglátása, hogy az ismeretlen a képzelőerőn keresztül fejti ki hatását, és a technikai tudás hiánya az olvasás sodrában alig tudatosul. Ezrek követték nyomon feszült figyelemmel az amerikai fregatt menekülését az Angol-csatornán, vagy az angol kereskedő üldözését és hajótörését a Révkalauzban, anélkül hogy egy kötél nevét tudnák a hajón, és mégsem sokallva vagy nem kívánva az ismeretlen szavakban rejlő részleteket.

Különösen ügyeltem rá, hogy a kéziratba csak saját benyomásaim kerüljenek bele úgy, ahogy akkor megéltem a történteket. A zár- szóban, amelyre ezúton hívom fel az olvasó figyelmét, adtam helyet a mások által sugallt gondolatoknak és meglátásoknak.

Mindezen okok és néhány barátom tanácsa vett rá arra, hogy a naplómat sajtó alá rendezzem. Ha a végeredmény számot tarthat a köz érdeklődésére, a tengerészek sorsára több figyelmet irányít, vagy segít árnyalni arról a képet, s ez végül intézkedésekhez vezet, amelyek soruk jobbra fordulását hozza, enyhít napi nehézségeiken, nagyobb ön- és megbecsüléshez segíti és Isten felé fordítja őket, akkor elértem a célom.

Boston, 1840. július

\section{Az indulás}

Augusztus 14. - kora délután indul Bostonból hosszú útjára hajónk, a Pilgrim³ ${ }^{3}$ hogy délről megkerülve a kontinenst Észak-Amerika nyugati partjára érjen. Már délben megjelentem a fedélzeten, teljes öltözetben, szívemben eltökélten a két-három éves utazásra, amelyre a gyógyulás reményében vállalkoztam, hogy szemem gyengesége így múljék, ha már azon orvos vagy orvosság segíteni nem tud. A teljes életmódváltás és a hosszú távollét a könyvektől és tanulástól talán segíthet állapotomon, amely eddigi törekvéseim feladására kényszerített.

A cambridgeporti ${ }^{4}$ diák szűk posztókabátját, selyemsapkáját és kecskebőr kesztyüit hátrahagyva, bár ez külsőleg meglehetősen

3 A hajó neve tükörfordításban: a Zarándok. Más értelemben: a legrégebbi, máig fennmaradt államokbeli angol település (Plymouth, Massachusetts) társalapítói a pilgrimek voltak. Alakjuk központi témája az Államok történetének, mint akik a vallási szabadságot és kulturális identitásuk megörzését remélték az áttelepüléstől.

${ }^{4}$ Massachusetts, Egyesült Államok; az eredetiben csak Cambridge. Egyébként a korban megszokott volt, hogy az orvosok hosszabb tengeri vagy tengerparti kikapcsolódást rendeltek el hasonló problémák esetén. A módosabb réteg - amibe a szerző is tartozott - általában európai hajókirándulást választott a célra. 
nagy változás, hamar fel lehet ölteni a tengerészek bő nadrágját, kockás ingét és vitorlavászon kalapját - gyorsan is ment. Úgy gondoltam, zöldfülühöz képest igencsak matróznak festhetek. Az e téren gyakorlott szemet azonban megtéveszteni lehetetlen, és én hiába tetszelegtem a magam szemében, mint Neptunusz méltó párja, nem kétséges, hogy a hajón messziről lerítt mindenkinek, hogy a tengert csak látásból ismerem. A matróznak ugyanis különös gondja van ruhájára, s ahogy azt hordja, azt zöldfülü utánozni nem képes. A nadrág bőre engedve, hogy csak a csípő tartsa meg, s így a szára teljesen leér egész a cipőig, és akörül terpeszkedik. A gondosan fényezett fekete kalap hátracsapva, amiről a bal szem előtt egy jó rőfnyi fekete szalag lóg. A fekete selyem nyakkendő különös kötése, aztán az a bizonyos kockás ing és még megannyi egyéb apróság pillanatok alatt árulja el, ki is új a vitorla alatt. De ha mindez még nem is lett volna elég, a fakó arcomra vagy a kezeimre egy pillantást vetve azonnal látható a különbség az igazi tengerész napégette arcához képest, aki ringó járásában, öles lépéseit kísérve lengeti bronzos, edzett kezeit, mindig nyitott tenyérrel, készen arra, hogy bármikor megragadjon egy kötelet.

Tehát „mindennel a homlokomra írva” csatlakoztam a legénységhez, majd nemsokára elhagytuk a dokkokat. A következő napon a kihajózásra készültünk fel: felkerültek a keresztrudak és a vitorlák a fóárbocokra, beállítottuk a segédvitorlákat, ahol kellett, ott védőkötést kapott a kötélzet, és felvettük a puskaport. Az éjjel első alkalommal osztottak be őrségbe. Az este első felében nem nagyon mertem aludni, hátha nem hallom meg, amikor az én szolgálatom következik és felhívnak a fedélzetre. Aztán amikor végre felhívtak, a zöldfülü ügybuzgalmával - nagyon fontosnak tartva megbízatásomat - sétáltam fel és alá a hajó egész hosszában, ki-kinézve az elülső és a hátsó korláton. Nem kicsit rökönyödtem meg, amikor az utánam következő öregmatróz, akit én hívtam váltásba, végül felkászálódott, hogy újabb helyet találjon aludni. Ez elegendő felvigyázás kellett legyen egy nyugodt éjszakára egy biztonságos öbölben horgonyozva - gondolhatta.

A következő reggel szombatra virradt, enyhe déli széllel. Miután felvettük a révkalauzt, felszedtük a horgonyt, és megindultunk az öbölből kifelé. A barátaimtól, akik kijöttek elbúcsúztatni, még elbúcsúztam, de egy utolsó pillantást vetni a városra és a benne kedves dolgokra már nemigen jutott idő - elvégre hajón nincs idő az érzelgésre. Az öböl szájáig jutottunk, amikor a szél szembefordult, s mi ismét horgonyt kellett vessünk. A nap hátralevő részére ottmaradtunk. Az ügyeletem a fedélzeten 11-kor kezdődött, és utasítást kaptam, hogy értesítsem a parancsnokot, mihelyst a szél nyugatira fordul. Jó szelet éjféltájt kaptunk, amire a parancsnok mindenkit a fedélzetre rendeltetett velem. Hogy ezt hogyan csináltam, máig sem tudom, de - bár kétségkívül nem ütöttem meg a gyakorlott fedélzetmester torkaszakadt üvöltése hangerejét - hamarosan csupa nyüzsgés lett a hajó. Leereszkedtek vitorlák, fordultak a vitorlarudak, és lassan felemeltük a horgonyt - az utolsó dolgot, ami jenkiföldhöz kötött minket. Azonban mindennek inkább voltam szemtanúja, mint részese. Nem tudtam ugyanis valami sokat a hajókról. Érthetetlen parancsok röpködtek, és már végre is hatották öket; a nagy sietség, a furcsa szavak és a még furcsább tettek zavaros egyvelegében teljesen elvesztem. Nincs gyámoltalanabb lény a Földön a kezdő tengerésznél. Az elnyújtott, ütemes nyögések jelezték, hogy a legénység épp a horgonyt emeli, s lassan megindultunk. Hallani lehetett, ahogy a hajó hullámot vet, s érezni, hogy engedelmesen meghajol és ring az esti szélnek. Mi pedig megkezdtük nagy utunkat. 


\section{Az első benyomások - „Vitorla a láthatáron!"}

$\mathrm{Az}$ első tengeren töltött napunk vasárnapra esett. A kikötőből frissen kifutva még bőven akadt tennivaló a hajón, ami egész napra ellátott minket teendővel - a rendrakáson dolgoztunk, aztán este következett az őrség. Ennek beosztását a hátsó fedélzeten ejtették meg, és amikor evégett hátrahívtak bennünket, megismerkedhettem a parancsnoki stílussal: az emberek kiválasztása után rövid, de karakteres beszédet intézett hozzánk. Ajkai közt szivar, így résnyire nyitott száján, két pöffentés között dörmögte a szavakat:

- Szóval emberek, hosszú útra indultunk. Ha jól kijövünk egymással, kellemes utunk lesz; ha nem, úgy ez a hajó maga lesz az úszó pokol. - Amit megkövetelünk, az az, hogy teljesítsék a parancsaikat és férfiként álljanak a munkához... - és akkor jól kijövünk. - Ha nem, akkor nem jövünk ki olyan jól. - Ezt tudhatom. Ha összetartunk, jó parancsnokukként ismerhetnek meg engem, ha nem, úgy egy veszett sakálként. - Ez minden mostanra. - Az őrség mehet pihenni.

Mivel engem a másodőrségbe osztottak be, azaz a másodtiszt alá, magaménak érezhettem a privilégiumot, hogy a nyílt tengeren az első ôrség az enyém. Ugyanebbe az őrségbe került egy korombeli fiatal, $S$, aki szintén első útján volt, s lévén az apja szakmabeli, ő maga pedig egy könyvelöirodában dolgozott Bostonban, sok közös ismerősünk és témánk akadt. Mindaddig folytattuk a beszélgetést - Bostonról, hogy mit csinálhatnak most a barátaink, az utunkról stb. - amíg az ö sora nem következett a felvigyázásban és ezzel magamra nem maradtam. Nagyszerü idő volt ez az elmélkedésre. Először éreztem magam körül a tökéletes tengeri csendet. A másodtiszt a hátsófedélzeten járkált, ahova nekem nem volt szabad mennem, néhányan beszélgettek közülünk, de nem éreztem késztetést, hogy csatlakozzak hozzájuk, így csak hagytam, hogy az engem ért benyomások érlelődjenek bennem. Bármennyire is megérintett a tenger szépsége, a ragyogó csillagok vagy az előttük gyorsan úszó felhők látványa, mégsem tudtam szabadulni a gondolattól, hogy az élet összes társasági és intellektuális örömeit hagyom most hátra hazámban. Viszont, tünjék akármilyen furcsának is, akkor és azóta is jó érzéssel töltenek az ilyen gondolatok, hiszen így remélhetem, hogy nem fognak kiveszni belőlem életem eddigi értékei.

De az álmodozásra ezúttal sem jutott sok idő: a tiszt utasítására a forduló szélhez kellett igazítanom az árbocrudakat. Abból, ahogy a többiek az eget vizslatták, és a gyorsan közeledő fekete felhőkből tudtam, hogy sok jóra nem számíthatunk, és hallottam a parancsnoktól, hogy úgy számolta tizenkettőre elérjük a Golfáramlatot. Pár perc múlva nyolcat kondítottak, őrségváltás volt, mi lementünk. Ekkor tapasztaltam meg a tengerészélet első keserüségeit. A fedélköz, ahol szolgálaton kívül voltam elszállásolva, tele volt pakolva kötéltekercsekkel, tartalékvitorlákkal, és mindenféle kacattal és kellékkel, amitől még nem szabadultak meg. Ráadásul nem volt hálóhelyünk kialakítva, és szegeket sem verhettünk be, hogy legyen hova akasztani a ruháinkat. Ahogy a tenger egyre nagyobbakat csapott, úgy himbálódzott mindinkább a hajó, és ezzel hunyt ki a rend utolsó szikrája is odalent. Minden összeborult és egymásra csúszott, vagy ahogy a tengerészek mondják: „fészket rakott a vihar”; ilyenkor „minden egymás-hegyén hátán van, de kéznél semmi sem". Egy tekercsnyi kötél épp a mellkasomon száguldott át; a kalapom, csizmám, matracom és pokrócom mind átcsúszott a mély oldalra - a kötelek meg a dobozok mind rá. Mindezek tetejébe nem használhattunk lámpást odalent, hogy könnyebb legyen kifürkésznünk mi merre van éppen, és a tengeri betegség is erös tünetekkel kezdett kiülni rajtam, a hozzátársuló kedvetlenséggel és tehetetlenséggel együtt. Föladva a reményt, hogyén most összeszedem a dolgaim, leheveredtem a vitorlákra, és vártam, hogy mikor hívnak min- 
denkit fel, ami a közelgö vihar miatt igencsak esedékes volt. Az eső kisvártatva kopogtatni kezdett a pallókon; nagy, sürün hulló szemekben érkezett. A fentiek keze alatt éghetett a munka, legalábbis ahogy az elsőtiszt hangos és többször elismételt parancsaiból, a lábak dobogásából, a deszkák fájdalmas recsegéséből és a vihar többi jeléből sejteni lehetett. Néhány perc múlva felcsapták a fedélköz ajtaját, ami így még kevésbé szürte meg a fenti zajokat, és leordították, hogy „Mindenki fedélzetre, ahoj! Irány fel és befogni a vitorlákat!", majd ugyanazzal a sebbel-lobbal be is vágták. Amikor felértem, meröben új látvány fogadott: a kis brigget úgy vitte a szél, hogy szinte belenyomta a vízbe: ahogy nekem tünt, a hajó szinte a fedélzetig belebukott a tengerbe. A hajó orrát mintha a pöröly erejével és zörejével csapkodták volna a hullámok, felcsapva a fedélzetre, bőrig áztatva minket. A csúcsvitorla kötelei kiengedtek, és a nagy vászonköteg mennydörgő hanggal vetődött hátra a fejünk felett. A szél fütyült a kötélzeten, elszabadult kötelek csapkodtak; hangos - persze számomra értelmetlen - parancsok hangzottak gyors egymásutánban, és hallatszott a „matrózok éneke”, ahogy minden erejüket megfeszítve birkóztak a kötelekkel.És ha ehhez még hozzáadom, hogy koromsötét volt, és mivel a szárazföld szilárd viszonyaitól még nem sikerült elszoknom, borzalmas hányinger kerülgetett, és alig volt erőm, hogy bármiben is meg tudjak kapaszkodni... Nos, ezen állapotomban parancsoltak fel elöször az árbocra, hogy bevonjam a csúcsvitorlákat.

Hogy hogyan is éltem túl, pontosan nem emlékszem. Kiterültem a keresztrúdon, és minden erőmmel csimpaszkodtam belé. A munkában nem sok hasznomat vehették, mert emlékeim szerint többször is elfogott a hányinger, csak mielőtt a legfelső rúdról lekászálódtam volna. A fedélzeten hamarjában végeztünk, és így ismét lemehettünk a fedélközbe. Ez azonban nem tünt megváltásnak, már csak ha a felfordulást vesszük, ami odalent volt, meg azt az orrfacsaró bűzt, amit a felbolydult és áporodott fenékvíz árasztott magából. Igénytelen menedék a fenti káosz elöl. Sokat olvastam mások tengeri élményeiről, de úgy éreztem, hogy az enyémnél aligha lehetett rosszabb akár egy is; és megkörnyékezett az a baljós gondolat, hogy ez csak az első éjszakája egy kétéves útnak. Később aztán a fedélzeten sem volt sokkal jobb, mivel a tiszt folyton utasítgatott minket, mondván, hogy jó, ha állandóan mozgásban vagyunk. De még ez is különb volt annál, mint ami lent volt. Nagyon is tisztán megmaradt bennem, hogy valahányszor, amikor odamentem a csapóajtóhoz, mert elfogott az émelygés, azonnal megkönnyebbültem, mihelyst lehajtottam a fejem. Hasonló hatása csak egy erős hánytató szernek lehet.

\section{A következő két nap nem hozott változást}

Augusztus 20. (szerda) - Miénk volt a hajnal négytől nyolcig tartó őrség. Mire feljöttünk, az időjárás jobbra fordult. A szél és vele a tenger lecsillapodott, a csillagok ismét fényesen ragyogtak. A kedélyállapotomban is hasonló javulást éreztem, de még mindig igen gyenge voltam a tengeribetegségtöl. A szél felöli oldalon álltam, ahonnan a Nap kelt fel. Sokat hallani a tengeri napkeltéről; de teljesen más, mint a szárazföldön. Hiányzik mellőle a madarak éneke, az ébredező emberek reggeli hangos nyújtózása, a látvány, ahogy az első napsugarak átkúsznak a fák ágai között, a háztetők, a templom tornyai és a dombok fölött. Így, bár nem olyan magával ragadó, semmi sem hasonlítható ahhoz, amikor a széles óceán mögül bújik elő a Nap:

Van valami a hajnali szürkületben... ahogy a szürkeség elkezd emelkedni a keleti horizonton és távoli derengése a vízre vetül, ami - nem tudván milyen mélység húzódik alattunk és milyen üres messzeség körülöttünk - úgy tölt el a magány érzésével, rémülettel és borúlátással, amire a természetben más nem képes. Ez az érzés lassan alábbhagy, ahogy 
a fény egyre erősödik és végül felkel a Nap, amivel kezdetét veszi az átlagos, monoton tengerész hétköznap.

Ilyetén gondolataimból a tiszt szava ébresztett: „Előre, a pumpához!” Úgy találtam, hogy nincs idő az álmodozásra, és az első reggeli fénnyel „dologra kell térni”. A többi „tétlenkedőt", nevezetesen a hajóácsot, a szakácsot és az inast is dologra küldve hozzáláttunk a vízpumpáláshoz és a fedélzet felmosásához. Ez a minden nap elején végrehajtott procedúra két órába kerül; és alig volt erőm végezni vele. Ahogy megvoltunk a kötélzet ellenőrzésével is, leültem egy kicsit, várva a hét kondításra, ami a reggeli jele. Amint a tiszt látta tunya testtartásom, felparancsolt a fóárbocra, hogy kenjem át a tetejétől a talpáig. A hajó himbálódzott egy kissé, s mivel már három napja nem ettem, erős késztetést éreztem, hogy azt mondjam: inkább várnák ezzel a reggeliig. De tudtam, hogy „a bikát a szarvánál kell megragadni”, s hogy amint ellenszegülnék vagy visszakoznék, abban a pillanatban egyszerre végem lenne. Szóval fogtam a zsíros vödröt, és felmásztam az árbocra. A hajó imbolygása a magassággal egyre jobban érződik, s a zsír szagával együtt ez újra kikezdte a gyomromat. Az árboc tetejéhez képest a fedélzet terra firma, szilárd talaj: nagy megkönnyebbülés volt ismét rálépni. Néhány percre rá hét kondítás jelezte az őrségváltás és a sebességmérés idejét: mi pedig elmentünk enni. Itt meg kell, hogy emlékezzek szakácsunk, egy egyenes kiállású fekete tanácsáról:

- Na már most barátom - mondta -, te alaposan kitisztultál már. Az otthoni miheztartásodból sincs már semmi. „Ideje új szelet kellene fogni a vitorlákba” - a szárazföldi édességeid vesd át a hajókorláton, és vegyél magadhoz inkább egészséges sózott marhát és tengeri kenyeret, és megígérhetem, hogy mire a Horn-fokhoz érünk, új erőre kapsz, és úgy állod meg a helyed a hajón, mint akárki más.

Az együttérző, udvarias szavak között ezt a jószívütanácsotismegemlíthetnékahajóktengeribetegutasainak:ahasznukraválna,állíthatom.
Le sem tudom írni azt a jótékony hatást, amivel a fél fontnyi hideg marhahús és az az egy vagy két kétszersült volt rám. Délig pihenőn voltunk, így jutott egy kis időm magamra, és a marhahúst - a szakács ajándékát - falatoztam. Mikor következőleg a fedélzetre léptem, újra embernek éreztem magam, és a megfelelő lelkesedéssel foghattam a munkához, hogy megtanuljam a tengeri élet csínját-bínját. Két óra körül hangos kiáltás jött az árbockosárból: „Vitorla a láthatáron!” Hamarosan feltűnt két vitorlás a szél felőli oldalunkon. Ez volt az első alkalom, hogy a tengeren láttam hajót. Akkor és azóta is úgy gondolom, hogy szépségben és látványban ez minden mást felülmúl. Előttünk haladtak el keresztirányban, hallótávolságon kívül; de a parancsnok távcsővel le tudta olvasni a nevüket: a Helen Mar volt az New Yorkból és a Mermaid ${ }^{5}$ Bostonból. Mindkettő nyugatra tartott, szeretett szülőföldünk felé.

Augusztus 21. (kedd) - A Nap tiszta égboltra kelt, jó szelünk és vidám reggelünk volt. Most, hogy már „megvetettem a lábam a tengeren", kezdtem beletanulni a dolgokba. Amikor hatot kondítottak, ami délután három órát jelöl, egy újabb hajó bukkant fel mellettünk. Mint minden újonc tengerész amikor hajót lát, én is alig bírtam, hogy ne vegyem máris a számra. Mellénk siklott, visszavette vitorláit, $\mathrm{s}$ a két hajó fej-fej mellett, szinkronban ringott a vízen, mint ahogy a fogat elé fogott lovak. Ez volt az első hajó, amit a tengeren közvetlen közelről is szemügyre vehettem, és meglepett, hogy mennyire ringatózik még az ilyen békés tengeren is. Fedélzete megtelt kíváncsi utasokkal, akik ruháik és megjelenésük alapján svájci vagy francia emigránsok lehettek. Először franciául üdvözöltek minket, de mivel választ nem kaptak, angolul is megpróbálkoztak. A La Carolina volt az, Le Havre kikötőjéből indult, és New Yorkba tartott. Kértük, hogy jelentse a Pilgrimet északnyugati irányban öt napra Bostontól. Aztán továbbállt, s mi egyedül foly-

\footnotetext{
5 Magyarul: „Hableány”.
} 
tattuk tovább hosszú utunkat. Jó időt fogtunk ki; a nap kellemesen és a szokásos rutin szerint telt, amit egyébként csak vihar, egy másik hajó vagy a szárazföld közelsége tör meg.

\section{Munkák a hajón - Trópusi vizeken}

Mivel az időjárás jó ideje kegyes volt hozzánk, s más problémák sem akadtak, amelyek a napok egyhangúságát megtörték volna, az alkalom most kiváló, hogy általában szóljak az amerikai hajós életéről, a munkáról, a szokásokról és a szabályokról, amelyek azt meghatározzák, s amelyek a mi hajónkon nagyjából úgy alakultak, mint a flottában általában.

Először is, és nem véletlenül elsőként: a parancsnok. Az abszolút nagyúr, aki nem áll őrt, jön és megy, ahogy a kedve tartja. Nem áll felette senki, nem számon kérhető senki által, és neki kérdés nélkül engedelmeskedni köteles még az elsőtiszt is. Felmentheti tisztjeit a munka alól, de akár tisztségüktől is megfoszthatja őket, hogy matrózként dolgozzanak tovább a többiek közt az előfedélzeten. Ha utas vagy rakományfelelős nincs a fedélzeten, mint ahogy a mi hajónkon, úgy méltósága - hacsak jelleme nem üt el nagyon attól, mint amilyen a kapitányoké lenni szokott - nem enged neki társaságot és ebből fakadó kedvtelést, legfeljebb csak annyit, amit a hatalom tudata és időnkénti gyakorlása adhat.

A hajó - ha úgy tetszik - miniszterelnöke, hivatalos szerve, ügyeletes és felelős tisztje: az elsőtiszt. Ő a főhadnagy, egy személyben felel a fedélzetért, a fedélközért és a navigációért. A parancsnok vele osztja meg elképzeléseit, majd rábízza a munka beosztását és felügyeletét. A munkát nem egyszerüen csak meg kell csinálni, hanem még jól is, $s$ a minőségért a felelősség ismét az övé. A kolléga vagy „csíf” - ahogy a hajón hívják - vezeti a hajónaplót, így ő felel a tulajdonosok és biztosítók felé, és rá van bízva a rakomány is, a berakodástól kezdve, a megőrzésen át egész a leszállításig. Mivel a parancsnok aligha alacsonyodik le odáig, hogy matrózokkal viccelődjön, a másodtiszt pedig a kutyát se érdekli, így rangjából eredően ő a legénység ügyeletes mókamestere is, mivel mindenki úgy érzi nevetnie kell, ha elsüt egyegy otromba viccet vagy megejt egy gonosz csínyt az emberek szórakoztatására.

A másodtiszté, ahogy a mondás is tartja, kutya egy megbízatás. Még nem tiszt, de már nem is matróz. A többi matróz nem gondol rá tisztként: ugyanúgy fel kell másznia az árboc legtetejére a csúcsvitorlához, és ugyanúgy bele kell mártania a kezét a kátrányba és a kenőzsírba, mint bárki másnak. A tengerészek pincéreként is emlegetik, mivel ô látja el a legénységet kötelekkel, zsinegekkel és a munkához kellő többi dologgal, és a fedélzetmesteri raktárba is neki van bejárása, ahol az ezekhez való szerszámok is vannak. A parancsnok a tekintélye fenntartását és a fegyelem erősítését, a rend betartatását várja tőle; az elsőtiszt árnyékában mégis teljesen másodlagos személynek számít, és a matrózokkal együtt kell dolgoznia. Egyike azoknak, akiknek kevés adatik, mégis sokat várnak el tőle cserébe. Fizetése rendszerint a duplája a közönséges matrózénak, a kabinban alszik és eszik; de szinte minden idejét a fedélzeten kell, hogy töltse, és másodikként ül az asztalhoz, vagyis azt eszi, ami a parancsnok és az elsőtiszt után marad.

A kamrás vagy hajóinas a parancsnok szolgálója, és felügyeli az éléstárat, ahonnan rajta kívül mindenki, még az elsőtiszt is ki van tiltva. Ezen kiváltságai elegek ahhoz, hogy az elsőtiszt - aki nem szívesen lát olyat a legénység közt, aki felett nincs korlátlan hatalma - ellenségként tekintsen rá. A legénység ugyanakkor nem tekinti maga közül valónak, szóval végső soron teljes mértékben a parancsnoktól függ.

A szakács a legénység pártfogója, és akit a kegyeibe fogad, annak módja nyílik nedves kesztyűit és harisnyáját megszáríttatni, vagy az éjszakai őrség alatt a konyhában pipára gyújtani. A kamrás és a szakács, illetve - ha vannak a hajón, úgy - a hajóács és a vitorlajavító nincsenek őrségbe osztva, és mivel egész 
nap dolgoznak, éjjel nyugovóra térhetnek, hacsak valamiért nem rendelnek mindenkit a fedélzetre.

A legénység, amennyire csak lehet, két egyenlő részre van osztva, akik az őrségeket adják. Ezek a csoportok a felettes tiszt után vannak elnevezve: az őrség az elsőtiszt, a másod- vagy váltóőrség pedig a másodtiszt alá tartozik. ${ }^{6}$ Ezek négyórás időközönként váltják egymást a szolgálatban, vagy ahogy mondani szokás mennek fel és le. Ha, példának okáért, az elsőtiszt ügyel az első esti őrségben nyolctól éjfélig, akkor ennek végén őrségbe hívják a másodtiszt embereit, az örség pedig lemegy a fedélközbe. Hajnal négykor aztán a másodőrség ismét feljön, és nyolcig marad a reggeli őrségben. Mivel az eddigi tizenkét órából ők nyolcat fenn voltak, míg a másik őrség csak négyet, a délelőtti őrség idejét - nyolctól délig - lent tölthetik. A hadihajók és néhány kalmár ezt a váltórendet tartja egész nap, mind a huszonnégy órában; de a mi hajónk, mint a legtöbb kereskedőhajó, mindenkit foglalkoztat déltől napestig, ha jó az időjárás.

Azoknak, akik nem voltak még a tengeren, hasznára lehet, ha ejtek egy-két szót az úgymond „korcsőrségekről” is. Ezek révén nem kell mindennap ugyanannak az örségnek ugyanakkor őrt állnia. Ezt úgy érik el, hogy a délután négytől esti nyolcig tartó őrséget kettéosztják: ezek a korcsőrségek; egy négytől hatig, a másik hattól nyolcig. A nap így nem hat, hanem hét őrségre van felosztva, és a beosztások így mindennap cserélődnek. A korcsőrségekre esik az esti szürkület, és mivel ilyenkor még tart a munka, ezek alatt mindenki a fedélzeten van. A parancsnok a hátsó fedélzeten sétálgat a szél felőli oldalon, az elsőtiszt a másikon, a másodtiszt pedig az elő- és a hátsó fedélzet közt. A kamrás ekkorra a munkája végére ért és feljött, hogy a konyhában együtt pipázzék a

6 Angolban a hajó jobb és bal oldalának nevével vannak illetve, de ilyen szóhasználatot nem találtam a magyarban. (a ford.) szakáccsal. A legénység a horgonyfelhúzón üldögél vagy heverészik az előfedélzeten: pipáznak, énekelnek, bővére eresztett történeteket mesélnek egymásnak. Este nyolckor nyolcat kondítanak a harangon, leengedik a mérőónt, a kormányost leváltják, a hajókonyhát bezárják, az esti őrség feláll, a többiek pedig lemennek a fedélközbe.

A következő napi munka hajnalban veszi kezdetét: az aktuális reggeli őrség felmossa és végigsikálja a fedélzetet. Ez a vizeshordók feltöltésével és a kötélzet igazításával rendszerint eltart hét kondításig (vagyis fél nyolcig), ami a reggeli idejét jelzi mindenkinek. Nyolctól aztán sötétedésig tart a munka, amit csak egy egyórás ebédszünet szakít meg.

Kis kitérőm zárásaként érdemes még szólnom a „napi munkáról“, s ezzel egyben eloszlatni egy szárazföldi mítoszt a matrózéletről. Meglehetősen gyakran hallani a vélekedést, miszerint a tengerész jóformán csak henyélni van a tengeren: „elvégre mi mást tudnának csinálni?" Bár a következtetés természetszerü, de olyan tévedés, amibe a szárazföldön gyakran beleesnek, és minden matróz a kötelességének érzi kijavítani, ha szóba kerül. Először is: a hajó rendje megkívánja, hogy mindenki dolgozzék valamit, amikor a fedélzeten van, leszámítva az estét és a vasárnapi ünnepnapot. Hacsak nem pont ekkor szemlélődik valaki, aligha fog egy fegyelmezett hajón matrózokat lébecolni látni. A tisztek dolga, hogy mindenkit munkában tartsanak, még akkor is, ha más teendő már nem maradt, mint levakarni a rozsdát a láncokról. A börtönben az elítélteket nem tartják annyira dolog és szigorú felügyelet alatt, mint a matrózt a hajón. Munka közben beszélgetni tilos, és habár a matrózok gyakran trécselnek, amikor a fedélzeten vagy egymás közelében vannak, mégis mindig abbahagyják, amikor tisztet éreznek a közelben.

A matrózmunkáról vajmi kevés elképzelése lehet annak, aki még nem volt a tengeren - eleinte magamnak se volt sok. Amikor elhagytuk Bostont, a következő egy-két hétben 
folyamatosan dolgoztattak minket, ami - gondoltam -, a hajó ráncba szedése a nagy útra, és hogy hamarosan a végére érünk, és nem marad más dolgunk, mint ami a vitorlákkal akad. Azonban a dolgoknak ez a rendje két éven keresztül folytatódott, és a második év végén legalább annyi tennivaló volt, mint az út elején. Ahogy a mondás is tartja: „a hajó olyan, mint egy kényes óra", vagyis mindig van rajta valami javítanivaló. Az induláskor a segédvitorlák kötélzetével bíbelődtünk, ellenőriztük a teljes futókötélzetet, és az elhasználódott kötelek helyébe újakat húztunk be; aztán következtek az állókötelek: feszítés, csere, javítás, mind az ezer különböző helyen és módon, ahol és ahogy csak elképzelhető. És ahol a számtalannyi kötél valahol kopásnak lett volna kitéve, mert hozzáért egy másik kötél vagy valamelyik keresztrúd, oda „védőkötést” kellett rakni. A kötések karbantartása, igazítása és cseréje kéthárom ember teljes munkaidejét kitölti végig az egész utazás során.

A következő dolog, amit számba kell venni, az az, hogy minden „apróság”, ami a hajón használatos - így a sodort kötél, a pólyázókötél, a rögzítő kötélgyürü stb. - az a hajón készül. A tulajdonosok elképesztő mennyiségü „régi kacatot" vásárolnak fel, hogy aztán a matrózok kezdjenek vele valamit: a kötelet szálakra bontják, ezeket kinyújtják, összecsomózzák, majd az egészet gombolyagba göngyölik. Ez a vékonyabb kötél aztán a legkülönbözőbb célokra van felhasználva, de a legnagyobb részét mégis újrasodorják. Erre a munkára minden hajón találni egy egyszerű kötélsodró gépet, avagy tekerőt, ami lényegében csak egy kerék és egy orsó. Ha jó az idő, a gép mellett folyton dolgoznak, és a hangja betölti a fedélzetet. Ez az utazás nagyobb részére szintén leköt három embert.

Egy másik mód a legénység elfoglalására a kötélzet beállítása. Ha az állókötélzet valahol meglazulna - ami pedig gyakran megesik -, akkor a kötélgyürüket és a védőkötéseket le kell venni, a csigákat felfuttatni, a kötelet jó erősre megfeszíteni, majd a gyürűket és a kötéseket visszatenni, ami szintén jó kis munka. A kötélzet ráadásul annyira összetett, hogy nemigen lehet egy kötélhez hozzányúlni anélkül, hogy egy másikhoz se kéne. A hátsó árbocmerevítőkön nem lehet dolgozni például anélkül, hogy ne engedne az elülső stb. stb. Ha mindehhez hozzávesszük még mind az összes kátrányozást, zsírozást, olajozást, fényezést, festést, kaparást és sikálást, amire egy hosszú út során szükség van, és nem feledkezünk meg az éjszakai őrségről, a kormányzásról, a vitorlák kurtításáról, felcsavarásáról, bevonásáról, kiengedéséről, beállításáról, meg a húzás-vonás-mászásról minden elképzelhető helyre és irányba, akkor aligha merül többet fel a kérdés, hogy „Mégis milyen teendőt találhat magának a tengerész a tengeren?”

Ha ezek után - megküzdve hideggel, vízzel, nyirokkal és viharral -,

„Ily éjszakán, hol meghúzná magát

A kölykes medve is, s az éhsanyarta

Farkas s oroszlán féltik börüket,"7

a kereskedő és a parancsnok úgy gondolnák, hogy a matrózok még nem érdemelték ki a havi tizenkét dollárjukat (amiből ruházzák magukat) és kosztjukat, akkor beállítják őket szálat tépni - ad infinitum, végtelenül. Ez a szokásos teendő az esős napokra, amikor a kötélzeten nem lehet dolgozni; és ahelyett, hogy a szakadó esőben megengednék a matrózoknak, hogy egyszerüen fedett helyre húzódjanak beszélgetni és elfoglalni magukat: elszeparálják őket a hajó legkülönbözőbb pontjain és ezt csináltatják velük. Megfigyeltem, ahogy az „alapanyagot” gondosan elhelyezik több helyen is, hogy az Egyenlítő környékén gyakori rövid viharok alatt is akadjon teendő. Néhány tiszt annyira károsnak tartja a pihenést, hogy a láncokat vagy a horgonyt - utóbbit elég gyakran - takaríttatják és kapartatják a legénységgel. A „philadelphiai katekézis” szerint:

„Az első hat napon dolgozz és tégy meg

7 Shakespeare Lear király; Vörösmarty fordítása. 
mindent, amit lehet. A hetediken borulj térdre és - végy horzsakőt, súrold fel a pallót és kapard le a láncot."8

A munkának ez a menete persze változik a Horn-foknál, a Jóreménység fokánál és máshol a nagyon északi vagy déli vizeken, de volt szerencsém látni frissen felmosott és -sikált fedélzetet akkor, amikor a víz csak azért nem fagyott meg, mert az ehhez használt tengervíz sós. Vagy amikor - hiába a vastag gyapjúkabát - mindenkinek a kötélzeten kellett dolgoznia olyan hidegben, hogy az ember elgémberedett kezében alig állt meg a bújtatófa.
Ebben a fejezetben az események fonalától azért tértem el, hogy a matrózlét valóságáról a lehető leghűbb képet alkothassa magának az olvasó, és azért itt, mert ekkor egy jó ideje már nem álltak már másból napjaink, mint ezen feladatok minduntalan ismétléséből. Ezeket a dolgokat egyébként is érdemes egy helyen összefoglalni. Végezetül még hozzáfüzném - annak érzékeltetésére, hogy a szárazföldről mennyire nem látni rá egy hajó üzemére - hogy a hajtótesten folyamatosan dolgozik az ács a tökéletes hajózórendben, vagyis ha jó az idő. * * Fordította PÉCSI István pecsi.istvan@outlook.com

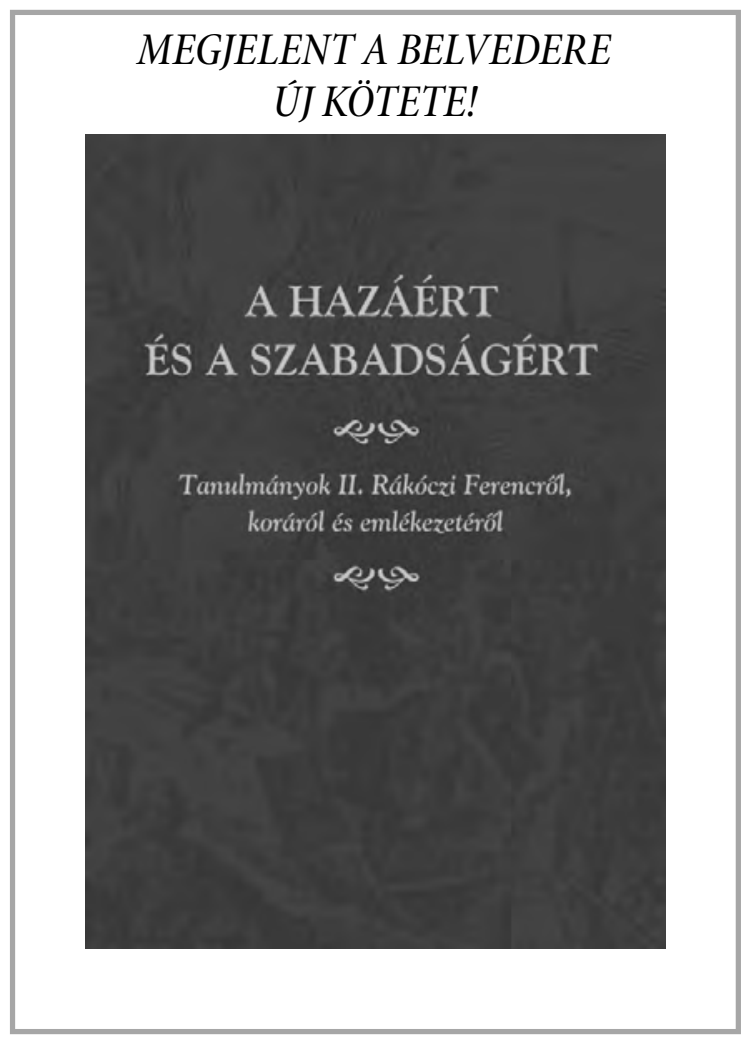

8 Lefordíthatatlan szójáték: a horzsakő angolul „holystone”, azaz szentkő. 